No $2005-13$

August

The Consequences of Agricultural Trade Liberalization for Developing Countries: Distinguishing Between Genuine Benefits and False Hopes

Jean-Christophe Bureau, Sébastien Jean \& Alan Matthews 
The Consequences of Agricultural Trade Liberalization for Developing Countries: Distinguishing Between Genuine Benefits and False Hopes

Jean-Christophe Bureau, Sébastien Jean \& Alan Matthews

No $2005-13$

August 


\section{TABLE OF CONTENTS}

2. AGRICULTURAL PROTECTIONISM IN DEVELOPED COUNTRIES 


\title{
The CONSEQUenCes OF Agricultural Trade Liberalization fOR DEVELOPING COUNTRIES: Distinguishing Between GeNuine Benefits ANd FAlSe HoPes
}

\begin{abstract}
SUMMARY
Because developing countries' comparative advantage is seen to lie in agriculture, the protectionist agricultural policies in OECD countries are often criticized for preventing developing countries benefiting from world trade. However, recent studies suggest that the positive effects of the elimination of Northern agricultural subsidies might have been overestimated. The very large gains for developing countries predicted by some models have recently been criticized on the grounds that they were largely driven by particular assumptions on market equilibrium (labor) and incomplete tariff data, and that excessive country aggregation hid the contrasting fortunes of the different developing country groups.
\end{abstract}

While export subsidies lead to market distortions, their elimination will not bring the large gains that some non governmental organizations expect. By focusing mainly on tariffs, international organizations might underestimate the potential gains of eliminating farm subsidies in developed countries, especially in sectors such as cotton. Indeed, the role of tariff reductions must be nuanced because of existing preferential access for developing countries. In the agricultural sector the non-reciprocal preferences granted so as to encourage "trade as aid" are well-utilized.

Overall, for most middle-income developing countries confronted with high protection in their main markets, liberalization can be a source of substantial growth in prospects and prices for a relatively high-performing export sector. For net food importing countries, including most of the LDCs and the small island developing states, and for cotton importing countries (North Africa, Bangladesh), agricultural trade liberalization may have overall negative consequences, because of terms of trade effects. For most sub-Saharan Africa and LDCs, negative consequences also result from the erosion of their preferential access to the EU and US market. Supply-side constraints and non-tariff obstacles (increasingly originating from the private sector, and as such not dealt with in WTO negotiations) are in addition likely to prevent the poorest countries from reaping due benefit from new market opportunities.

These constrasting effects have long been underestimated. They are now supported by a growing body of quantitative analyses that have challenged the idea that cutting agricultural tariffs and ending farm subsidies would benefit developing countries as a whole. However, showing that the situation is complex has not made the policy message simpler. Indeed, while it becomes clear that some of the poorest countries are likely to lose from an agricultural agreement in Doha, some of the beneficiaries include a large number of poor people (China, India, Brazil, Thailand). In addition, in net food importing countries, the large losses for some agents consumers are offset, at least partially, by gains for other agents (urban consumers vs farmers). 
Under the WTO, the Special and Differential (S\&D) treatment mainly consists in a lower level of obligations and longer implementation periods to phase in trade discipline. Basically, these are mainly options for opting out the liberalization process, which are unlikely to alleviate possible negative effects resulting from multilateral liberalization in third countries. If the international community wants to offset some of the negative effects of the Doha round, more ambitious and positive measures must be implemented than the provisions of the Uruguay Round Agreement on agriculture.

\begin{abstract}
Recent analyses suggest that the impact of agricultural trade liberalization on developing countries will be very uneven. Simulations suggest that the effects of agricultural trade liberalization will be small, overall, and are likely to be negative for a significant number of developing countries. The Doha Round focuses on tariff issues, but some developing countries currently have practically duty-free access to European and North American markets under preferential regimes. Multilateral liberalization will erode the benefits of these preferences, which are presently rather well utilized in the agricultural sector. While South American and East Asian countries should benefit from an agricultural agreement, African and Caribbean countries are unlikely to do so. The main obstacles to the exports of the sub-Saharan African and Least Developed Countries appear to be in the non-tariff area (sanitary, phytosanitary standards) which increasingly originate from the private sector and are not dealt with under the Doha framework (traceability requirements, etc.). An agreement in Doha is unlikely to solve these problems and open large markets for the poorest countries. While this is not an argument to give up multilateral liberalization, a more specific and differentiated treatment should be considered in WTO rules, and corrective measures should be implemented.
\end{abstract}

Keywords: $\quad$ Agricultural Trade Liberalization, WTO, Developing countries. JEL classification: $\mathrm{F} 13, \mathrm{Q} 17$ 


\section{LES CONSÉQUENCES D'UN LIBÉRALISATION DU COMMERCE AGRICOLE POUR LES PAYS EN DÉVELOPPEMENT : AUTHENTIQUES BÉNÉFICES ET FAUX ESPOIRS}

\section{RÉSUMÉ}

Les politiques agricoles protectionnistes des pays de l'OCDE sont souvent critiquées au motif qu'elles empêchent les pays en développement (PED) de bénéficier du commerce international de produits agricoles, dans lequel on suppose généralement qu'ils bénéficient d'un avantage comparatif. Des études récentes suggèrent cependant que l'effet positif d'une élimination des mesures de protection de l'agriculture au Nord a été surestimé. La prédiction de très larges gains pour les PED a été récemment critiquée comme découlant en grande partie d'hypothèses spécifiques sur l'équilibre des marchés (du travail en particulier), de données de protection incomplètes et d'une agrégation excessive masquant les intérêts contrastés des différents groupes de PED.

Si les subventions aux exportations sont bien à l'origine de distorsions de marché, leur élimination n'amènerait pas pour autant nécessairement les gains importants que certaines organisations non gouvernementales en attendent. En se concentrant sur l'accès au marché, les organisations internationales sous-estiment par ailleurs les gains potentiels de l'élimination des soutiens à l'agriculture dans les pays développés, en particulier dans des secteurs comme le coton. Le bénéfice potentiel d'une libéralisation de l'accès au marché doit être nuancé du fait des régimes préférentiels déjà accordés aux PED. Dans le secteur agricole, les préférences non réciproques accordées pour encourager le commerce comme vecteur d'aide (trade as aid) sont bien utilisées.

$\mathrm{Au}$ total, pour la plupart des pays à revenu intermédiaire confrontés à un forte protection sur leurs principaux marchés, la libéralisation peut être une source de croissance substantielles des perspectives et des prix de leur secteur exportateur, relativement performant. Pour les pays importateurs nets de produits alimentaires, ainsi que la plupart des pays les moins avancés (PMA), les petits pays insulaires en développement et les pays importateurs nets de coton (Afrique du Nord, Bangladesh), la libéralisation agricole pourrait bien avoir des conséquences négatives, en raison d'un dégradation de leurs termes de l'échange. Pour les pays d'Afrique subsaharienne et les PMA, l'effet négatif résulterait aussi largement de l'érosion de leur accès préférentiel aux marchés de l'Union européenne et des Etats-Unis. Les contraintes d'offre et les obstacles non tarifaires (émanant de plus en plus souvent du secteur privé et échappant de ce fait aux disciplines de l'Organisation mondiale du commerce) gêneraient en outre considérablement les pays les plus pauvres pour tirer bénéfice des opportunités nouvelles qui leur seraient offertes.

L'hétérogénéité de ces effets a longtemps été sous-estimée. Elle est maintenant soulignée par un nombre croissant de travaux, qui remettent en cause l'idée selon laquelle la baisse des barrières douanières et la suppression des subventions à l'agriculture bénéficierait à l'ensemble des PED. Montrer que la situation est complexe ne simplifie cependant pas le message de politique économique. En effet, alors même qu'il devient clair que certains des pays les plus pauvres pourraient bien perdre à un accord sur l'agriculture dans le cycle de 
Doha, les bénéficiaires incluent un très grand nombre de pauvres (notamment en Chine, en Inde, au Brésil ou en Thaïlande, par exemple). De surcroît, dans les pays importateurs net de produits alimentaires, les pertes des consommateurs sont compensées, au moins partiellement, par les gains d'autres agents (consommateurs urbains vs. agriculteurs).

Le traitement spécial et différencié à l'OMC consiste essentiellement en un moindre niveau d'obligations et de plus longues périodes de mise en œuvre des discipline commerciales. Il s'agit essentiellement de mesure permettant de se soustraire au processus de libéralisation, qui sont peu susceptibles de soulager les effets négatifs résultant d'une libéralisation commerciale dans des pays tiers. Si la communauté internationale veut compenser les effets négatifs potentiels du cycle de Doha, des mesures correctives plus ambitieuses que celles du cycle précédent doivent être mis en œuvre.

\section{RÉSUMÉ COURT}

Les analyses récentes suggèrent que l'impact sur les pays en développement (PED) d'une libéralisation du commerce de produits agricoles serait très varié. D'après les simulations, cet impact serait faible dans l'ensemble et probablement négatif pour nombre de PED. Le cycle de Doha se concentre sur l'accès au marché, alors qu'un certain nombre de pays pauvres bénéficient déjà d'un accès libre de droits aux marchés européen et nord-américain, grâce aux régimes préférentiels. Une libéralisation multilatérale éroderait le bénéfice de ces préférences, qui sont actuellement très bien utilisées dans l'agriculture. Si les pays sudaméricains et est-asiatiques apparaissent en position de tirer bénéfice d'un accord dans l'agriculture, tel n'est pas le cas de la plupart des pays africains et caribéens. Les principaux obstacles aux exportations des pays d'Afrique subsaharienne et des pays les moins avancés (PMA) semblent se trouver dans le domaine non tarifaire (normes sanitaires et phytosanitaires), qui émanent de plus en plus fréquemment du secteur privé (exigence de traçabilité, etc.) et tendent de ce fait à échapper aux compétences de l'Organisation mondiale du commerce. Un accord multilatéral ne devrait pas résoudre ces problèmes ni ouvrir de marchés substantiels aux pays les plus pauvres. Ce constat n'implique pas qu'il faille renoncer à la libéralisation multilatérale, mais plutôt qu'un traitement spécial et différencié plus ciblé devrait être étudié à l'OMC et que certaines mesures correctives devraient être mises en œuvre.

Mots Clés: $\quad$ Libéralisation du commerce de produits agricoles, OMC, pays en développement.

Classement JEL: $\quad$ F13, Q17 


\section{THE CONSEQUENCES OF AGRICULTURAL TRADE LIBERALIZATION FOR DEVELOPING COUNTRIES: Distinguishing BetWeEn GeNuINe BENEFITSAND FALSE HOPES

\author{
Jean-Christophe Bureau $^{\text {abc }}$, Sébastien Jean ${ }^{\mathrm{b}} \&$ Alan Matthews ${ }^{\text {ad }}$
}

\section{INTRODUCTION}

Because developing countries' comparative advantage is seen to lie in agriculture, the protectionist agricultural policies in OECD countries are often criticized for preventing developing countries benefiting from world trade (Oxfam, 2005). Indeed, many studies suggest that developing countries will reap most of the benefits of trade liberalization, and that the gains for them would be considerable if an ambitious agreement brought about freer trade (Hertel et al 2003; World Bank 2004).

However, recent studies suggest that the positive effects of the elimination of Northern agricultural subsidies might have been overestimated (Panagaryia, 2004). The very large gains for developing countries predicted by some models have recently been criticized on the grounds that they were largely driven by particular assumptions on market equilibrium (labor) and incomplete tariff data, and that excessive country aggregation hid the contrasting fortunes of the different developing country groups (Bouët et al 2004a). The fact that many modelers use the same set of data and parameters had encouraged an illusion of consensus regarding the magnitude of the benefits of trade liberalization, which are now revised downwards. ${ }^{1}$ Typically, simulations of a Doha agreement on agriculture (which would only bring partial liberalization) now suggest welfare changes for developing countries that range between a loss of 2 billion US dollars a year (Bouët et al 2004a) to a

\footnotetext{
a Institute for International Integration Studies, Trinity College Dublin.

bentre d'Etudes Prospectives et d'Informations Internationales, Paris.

Institut National Agronomique Paris-Grignon.

d Department of Economics, Trinity College Dublin. This author acknowledges the support of the Advisory Board for Development Cooperation Ireland for this research

Corresponding author: J.C. Bureau, Email: bureau@grignon.inra.fr. Tel: +353 16083196.

Most general equilibrium models rely on the Global Trade Analysis Project, which enables modelers to pool their resources and to reduce the gigantic task of gathering data. Version 5 of the GTAP dataset did not include the preferential tariffs granted by some major developed countries to the developing ones and therefore led to overestimate the benefits of liberalization for developing countries. The 2005 release of a new version (GTAP 6) and the availability of data on applied tariffs (MacMap) have led to a significant revision of the conclusions drawn from simulations. Estimates of smaller welfare gains also result from a more recent benchmark (2001 instead of 1997), and the fact that some liberalization had taken place since 1997.
} 
gain of some 12 billion dollars (Anderson and Martin 2005). These results are far below the estimates that were published only a few months earlier by most institutions.

It is also becoming apparent that the consequences of agricultural liberalization for developing countries are complex, and that claims that developing countries as a whole would reap the benefits are misplaced. The consequences of a Doha agreement on agriculture will be uneven both between countries and between economic agents (typically consumers and agricultural producers). This raises questions about the strategies to minimize the losses, for ethical reasons as much as for gathering a consensus to support the multilateral process. Some of the losses experienced by developing countries result from the erosion of existing preferential access to EU and US markets. The ability of "special and differential treatment" for developing countries (a principle underlying all World Trade Organization agreements) to cushion potential negative effects, and the ability of existing non-reciprocal preferences for these countries to provide benefits for the most needing countries require some examination.

In this paper, we take a closer look at the effects of the Doha agricultural negotiations on developing countries. We try to distinguish the different effects at stake and to identify the consequences for different country groups. We also analyze the separate impact of the different policy instruments, such as export subsidies, domestic support and tariff protection. We find that, while export subsidies lead to market distortions, their elimination will not bring the large gains that some non governmental organizations expect. By focusing mainly on tariffs, international organizations might underestimate the potential gains of eliminating farm subsidies in developed countries, especially in sectors such as cotton. Indeed, the role of tariff reductions must be nuanced because of existing preferential access for developing countries. We show that, in the agricultural sector the non-reciprocal preferences granted so as to encourage "trade as aid" are well-utilized, even though the benefits are limited for the poorest countries, because of supply side and nontariff constraints. Overall, we believe that a further step in special and differential measures is needed to adjust to the negative effects of agricultural negotiations on selected countries, even though more discrimination between developing countries faces conceptual, legal and political obstacles.

\section{AGRICULTURAL PROTECTIONISM IN DEVELOPED COUNTRIES}

The extent of agricultural protection. The agricultural protectionism of the Northern countries has long been denounced by developing countries. However, the results of impact studies are contradictory, and reflect some of the agenda of the different parties in the multilateral negotiations. For example, the Cairns Group and the United States emphasize the effects of "fortress Europe" on poor countries, while the European Commission stresses how the EU tariff structure allows it to import some eight times more agricultural foodstuffs from developing countries than Australia and United States combined. Technical difficulties have fuelled the controversy on the actual level of agricultural protection. The simple measure of duty on agricultural products yields varying figures depending on the type of average used (trade weighted or not), and whether one 
focuses on bound or applied tariffs. ${ }^{2}$ Bound tariffs negotiated at the WTO represent commitments on maximum tariffs, but much lower tariffs are sometimes applied, especially by developing and transition economies. In the case of the EU, lower tariffs are applied under preferential agreements and tariff rate quotas. Of the 148 members of the WTO, only ten do not benefit from some form of preference from the EU. The others, including all developing countries, can export to the EU with zero or reduced tariffs on at least certain products. The United States also has numerous preferential regimes, arising either from free trade agreements or in the framework of non-reciprocal regimes (African Growth Opportunity Act -AGOA, Caribbean Basin Economic Recovery Act, etc.). Every developed country also grants non-reciprocal preferences to developing countries within the framework of the Generalized System of Preferences (GSP). For this reason, the level of agricultural protection in a given country is not very meaningful per se. It must be gauged relative to the structure of exports from each country, and this requires requires bilateral measures of applied tariffs, which were made available only recently (Bouët et al, 2004b). The use of such measures shows that obstacles to exports from developing countries are significant in Japan, where preferential systems have only a limited effect in agriculture. The protection level is also higher in the European Union than in the United States (Bureau and Salvatici, 2004). In the United States (sugar, dairy, tobacco), and more so in Canada (dairy), protection is concentrated in a few sectors. It is more widespread across products in the European Union. Indirect protection through subsidies is also pernicious, as in the case of cotton in the United States. Assessing Australian protection is difficult as it is essentially non-tariff based (Fontagné and Mimouni 2001). Finally, tariff protection is still high in developing countries, in particular in those that may represent a large market for other developing countries (India, and, in some sectors, China).

Table 1 provides an estimate of applied tariffs for different agricultural sectors, for groups of countries. It shows that protection remains very high in some agricultural sectors, particularly in Europe and Asia, including for products of significant interest for developing countries, such as sugar. Table 2 also shows that Northern agricultural protection does not have the same effects on every developing country. The protectionist nature of the European Union, for example, affects particularly South American and Asian exporters. However, African countries face a lower tariff because they can export to the EU under more generous preferential agreements than, say, Brazil or Thailand. Recent work also shows that most Asian and South American developing countries face particularly high tariffs for processed food products, which encourages exports of raw materials rather than processed ones. This issue of tariff escalation is much less severe for sub Saharan African exports to EU markets, again because of the existing preferences under the Cotonou or Everything But Arms schemes (Bureau et al 2004).

\footnotetext{
${ }^{2}$ For example, different authors provide estimates of the EU average tariff for agricultural products ranging from $10 \%$ to $40 \%$, the figures by Gallezot (2003) contrasting with those of Messerlin (2001). See Bureau and Salvatici (2004) for a comparison.
} 
The Consequences of Agricultural Trade Liberalization for Developing Countries

Table 1. Average tariffs applied by sector, per cent

\begin{tabular}{lccccc}
\hline & EU 25 & USA & $\begin{array}{c}\text { Asia } \\
\text { Developed }\end{array}$ & EFTA & $\begin{array}{c}\text { Cairns } \\
\text { Developed }\end{array}$ \\
\hline Paddy rice & 62.9 & 4.6 & 289.9 & 12.3 & 0.0 \\
Processed rice & 138.1 & 4.9 & 314.0 & 11.6 & 0.0 \\
Coarse grains & 24.3 & 1.1 & 83.9 & 82.6 & 0.1 \\
Wheat & 0.5 & 2.4 & 69.2 & 134.4 & 1.2 \\
Sugar & 128.5 & 34.8 & 120.4 & 48.2 & 3.5 \\
Oilseeds & 0.0 & 4.3 & 62.4 & 38.5 & 0.1 \\
Live animals & 36.2 & 0.1 & 20.4 & 53.6 & 0.0 \\
Animal products & 4.3 & 0.6 & 9.9 & 33.7 & 8.3 \\
Meat & 62.8 & 3.2 & 25.2 & 177.6 & 5.9 \\
Meat products & 20.0 & 3.6 & 31.8 & 167.9 & 30.4 \\
Dairy products & 39.6 & 18.8 & 40.2 & 91.7 & 76.6 \\
Fibers & 0.0 & 1.6 & 0.2 & 0.0 & 0.0 \\
Fruits \& vegetables & 17.9 & 2.7 & 17.1 & 31.8 & 1.7 \\
Other crops & 2.3 & 2.7 & 3.7 & 20.0 & 1.4 \\
Fats & 4.6 & 3.5 & 4.2 & 36.2 & 2.1 \\
Beverage Tobacco & 13.7 & 2.4 & 13.1 & 15.9 & 7.2 \\
Food & 10.1 & 4.2 & 12.6 & 20.8 & 6.8 \\
Total agrofood & 16.7 & 4.7 & 22.5 & 47.7 & 10.8 \\
\hline
\end{tabular}

Source: MacMap_HS6,using ad valorem equivalents. The figures indicate the percentage tariff, weighted by the exports of a reference group of countries so as to account for the relative importance of each product without suffering from the well known endogeneity bias of regular trade weighted averages. See Bouët et al 2004b.

Table 2. Average applied bilateral tariffs in the agricultural sector, per cent

\begin{tabular}{lccccc}
\hline $\begin{array}{l}\text { Tariffs applied by } \rightarrow \\
\text { applied to } \downarrow\end{array}$ & EU 25 & USA & Asia developed & EFTA & $\begin{array}{c}\text { Cairns } \\
\text { developed }\end{array}$ \\
\hline EU 25 & - & 5.8 & 22.2 & 52.0 & 15.7 \\
USA & 16.2 & - & 28.9 & 57.9 & 5.1 \\
Asia developed & 12.5 & 3.7 & - & 17.9 & 6.2 \\
EFTA & 7.9 & 3.9 & 11.6 & - & 10.6 \\
Cairns developed & 25.9 & 3.4 & 24.9 & 79.8 & - \\
Mediterranean & 7.3 & 4.0 & 14.1 & 25.7 & 3.7 \\
Sub-Saharan Africa & 6.7 & 3.0 & 12.0 & 8.9 & 0.7 \\
Cairns developing & 18.3 & 3.8 & 24.0 & 34.7 & 5.9 \\
China & 13.5 & 5.1 & 21.7 & 36.7 & 8.7 \\
South Asia & 14.4 & 1.8 & 33.7 & 21.9 & 1.8 \\
Rest of the World & 15.1 & 2.1 & 17.4 & 25.8 & 2.6 \\
Average & 16.7 & 4.7 & 22.5 & 47.7 & 10.8 \\
\hline
\end{tabular}

Source: MacMap_HS6 using ad valorem equivalents. Weighted by exports of a reference country group (see Bouët et al 2004b). 
The cost of agricultural protectionism for developing countries. Even though better data on applied tariffs has led to a downward revision of some earlier estimates, agricultural protectionism in the North still significantly restricts exports from developing countries. OECD agricultural protectionism costs developing countries some 26 billion dollars (while the protectionism of Southern countries costs slightly more) according to Anderson and Martin (2005). Other studies find gains in the order of 4 to 8 billion dollars annually for developing countries if developed countries fully opened their agricultural markets (Diao et al 2004 ; Tokarick, 2003), and gains of about 1 to 3.5 billion dollars in the case of a lowering by half of the agricultural tariffs in developed countries (Francois et al 2003, for example). These net estimates are modest, when expressed as a percentage of GDP. They rely on welfare measures, and take into account all impacts, including possible unfavorable effects for consumers linked to price rises. The cost of agricultural protectionism is larger if attention is focused on developing country producers alone.

However, the gains from a cut in multilateral tariffs would be limited, if not negative, for the countries that already benefit from reduced tariffs. Bouët et al (2004a) find that sub Saharan Africa suffers more from the domestic support policies of developed countries (cotton in particular) than from their tariff structure due to their preferential access to the EU and US markets. Eliminating multilateral tariffs in developed countries would actually have negative effects on African countries because these countries would face more competition from, say, Australia or Brazil on the EU market. More generally, the reduction in multilateral tariffs in developed countries would generate an erosion of preferences detrimental to sub-Saharan African, Caribbean countries and Least Developed Countries (LDCs) in general. These results, echoed by those of Laird et al (2004), temper optimism on the effects of a multilateral reduction of tariffs for developing countries as a whole, by highlighting the negative consequences of agricultural liberalization for a set of countries that includes some of the poorest ones.

\section{PREFERENCES GRANTED TO DEVELOPING COUNTRIES}

Preferential market access. Developed countries have granted non-reciprocal preferences to particular sets of developing countries, which often reflect particular political or historical links. These preferences explain some of the uneven consequences of multilateral liberalization. If sub-Saharan Africa risks not benefiting much from lowered tariffs in a multilateral framework, it is because it benefits from preferential access to the European market under the Cotonou Agreement with African-Caribbean-Pacific countries (ACP) and to the US market under the AGOA (African Growth and Opportunity Act). Most other countries only benefit from the GSP, which has limited coverage for agricultural produce (the GSP nevertheless provides a much larger product coverage for LDCs, especially in the United States, and in the European Union under the specific component, the Everything But Arms initiative). 
Preferences which were designed to offer commercial potential to developing countries are much criticized. Preferences are said to be poorly utilized, in part because the rules of origin governing eligibility are restrictive and they largely limit the benefits of the preferences (Brenton, 2003). Preferences are often tied to restrictive or debatable conditions, subject to frequent changes, and therefore fail to provide the stable environment necessary to develop production (Panagaryia, 2003). They are accused of providing incentives for a country to specialize in products for which it has no comparative advantage. Preferences are also said to divert trade between developing countries and to create as many losers as winners. It is claimed that preferences have no or even a negative effect on growth and delay growth-promoting reforms (Ozden and Reinhardt; 2003, Topp, 2003). Finally, preferences are also under attack in the World Trade Organization (WTO) as contradicting the basic normative principle of non-discrimination.

Some of the criticisms of preferences seem less substantiated in agriculture than in other sectors. This is the case of the underutilization of the preferences, and the baneful effect of rules of origin. Others criticisms nevertheless apply.

The utilization of preferences in agriculture. Recent studies by OECD (2005) and Wainio et al (2005) show that, contrary to a widespread belief, commercial preferences granted to developing countries by the European Union and the United States are rather well utilized for agricultural products. Among exports from developing countries, those eligible are essentially exported under these preferences. In both the EU and the US, only a small share (about $11 \%$ and 13\% respectively, see Tables 3 and 4 ) of eligible agricultural products were exported outside a preferential regime. These rare cases of eligible exports under the Most Favored Nation (MFN) regime are largely explained by small trade flows and/or low MFN tariffs which means that the importer did not judge it worthwhile to meet the eligibility criteria (OECD 2005). In all other cases, a product eligible for a given preferential regime will be imported either under this regime, or under an alternative regime providing similar advantages. Studies inferring poor use of preferences might be valid in other sectors such as textiles but they are not supported by the available data for the agricultural, food and fisheries sector.

Some preferential regimes granted to developing countries appear more generous than others. Table 3 and Table 4 show that when exporters have the choice between two preferential regimes, they tend to favor particular agreements such as Cotonou for the European Union or the Caribbean Basin agreements for the United States. The main explanation is that these agreements impose less administrative constraints, or are more flexible regarding to the origin of the material used as inputs to exports than competing agreements. In the case of the United States, the GSP is also less predictable and has a shorter term horizon than the Caribbean Basin and Central America preferences.

\footnotetext{
${ }^{3}$ While the GSP has a legal status within the WTO (arising from the 1979 GATT "Enabling Clause"), a waiver must be sought for all regional preferences which are normally not covered by the Enabling Clause.
} 
Table 3. Utilization of US non reciprocal preferences for agricultural and food products, year 2002

\begin{tabular}{lcccc}
\hline Regime used & $\begin{array}{c}\text { Imports eligible, } \\
\text { by regime, 1000 } \\
\text { USD }\end{array}$ & $\begin{array}{c}\text { Actual import } \\
\text { under the regime } \\
\text { 1000 USD }\end{array}$ & $\begin{array}{c}\text { Apparent rate } \\
\text { of utilization }\end{array}$ & $\begin{array}{c}\text { Effective rate of } \\
\text { utilization }\end{array}$ \\
\hline NON RECIPROCAL & {$[1]$} & {$[2]$} & {$[3]=[2] /[1]$} & $\begin{array}{c}\text { Imports under any of } \\
\text { the } 4 \text { preferential } \\
\text { REGIMES }\end{array}$ \\
regimes / [1]
\end{tabular}

* excluding eligibility to regular GSP. Source: computation by authors from USITC data, based on CIF imports for 2002, chapters 1 to 24 of the HS96. The effective rate of utilization is constructed as the ratio of imports under any preference to the imports eligible for a given preference.AGOA is the Africa Growth Opportunity Act. ATPA indicates the Andean Trade Preference Act. CBI is the Carbbean Basin Initiative (now CBERA and CBTPA).

\section{Table 4. Utilization of EU non reciprocal preferences} for agricultural and food products, year 2002

\begin{tabular}{|l|c|c|c|c|}
\hline $\begin{array}{l}\text { Regime } \\
\text { Used }\end{array}$ & $\begin{array}{c}\text { Import eligible } \\
\text { by regime } \\
1000 \text { Euros }\end{array}$ & $\begin{array}{c}\text { Actual Import } \\
\text { under regime } \\
1000 \text { Euros }\end{array}$ & $\begin{array}{c}\text { Apparent rate } \\
\text { of utilization }\end{array}$ & $\begin{array}{c}\text { Effective rate of } \\
\text { utilization }\end{array}$ \\
\hline $\begin{array}{l}\text { NON } \\
\text { RECIPROCAL } \\
\text { REGIMES }\end{array}$ & {$[1]$} & {$[2]$} & {$[3]=[2] /[1]$} & $\begin{array}{c}\text { Imports under any of the } \\
\text { 4referential regimes / } \\
{[1]}\end{array}$ \\
\hline Total & 18609825 & 12292289 & $89 \%$ & \\
\hline Cotonou (ACP) & 5926849 & 5500091 & $92.8 \%$ & $95 \%$ \\
\hline GSP (regular) & 8754532 & 4385644 & $50.1 \%$ & $86 \%$ \\
\hline GSP-Drug & 1833684 & 1714354 & $93.5 \%$ & $95 \%$ \\
\hline E.B.A & 1682244 & 293527 & $17.4 \%$ & $96 \%$ \\
\hline & & & & \\
\hline
\end{tabular}

Source: Computations by J. Gallezot, from Taxud (Single administrative declaration) and TARIC data, based on CIF imports data for 2002, chapters 1 to 24 of the HS96. The effective rate of utilization is constructed as the ratio of imports under any preference to the imports eligible to a given reference. GSP Drug indicates the special GSP provisions for countries combating drug trafficking. EBA is the Everything but Arms Initiative. MFN stands for Most Favored Nation

Rules of origin. The criticisms of preferential regimes are less substantiated in agriculture than in other sectors with respect to rules of origin. Such rules have been shown to impose considerable constraints on would-be users of preferences, for example, in the textile industry (Brenton 2003, Inama 2003). T 
hey prevent non-cotton producing countries from exporting apparel and garments. For example, under preferences granted by the United States, non-cotton producing countries must sometimes work with US cotton in order to export tee-shirts within the preference regime.

In the food sector, the problem is less severe, perhaps because a large proportion of the exports of developing countries are primary goods not affected by the rules governing origins of components or intermediate inputs. In most cases, other obstacles (technical standards, poor infrastructure) appear more restrictive than rules of origin in the food sector, if we are to believe enquiries carried out among processors by Bureau et al (2004) and by OECD (2005).

However, a number of small countries experience problems justifying enough local content and being able to export processed foods. Stevens and Kennan (2004) raise this issue for several sub Saharan African countries. In the fisheries sector, they stress, for example, the difficulties for countries with a small maritime domain to supply processing plants all year round, given that origin is linked to the catching regions. In such cases, rules of origin do limit the benefit of preferential access. A particular problem posed by EU rules of origin is the lack of cumulation among countries that benefit from the GSP, except within a handful of regional groupings. Allowing further cumulation (i.e. considering material used by country A and originating from country B as "local" provided that country A and B are both eligible for the EU preference) would make it easier to make use of the GSP. In the case of the Everything But Arms initiative, which as part of the GSP is subject to the same restrictions, cumulation with all other developing (and perhaps all neighboring) countries would be necessary, since cumulation would bring little practical advantage if it were restricted to other LDCs. In the United States, the rules of origin impose a value added content, but also traceability of the material purchased, which requires significant compliance costs for countries where the production sector is fragmented and lacks administrative capacity.

Other limitations of preferential regimes. Some other criticisms of preferences apply to the agricultural sector. It is true that some countries have developed industries on which they are now very dependent, in areas where they have little comparative advantage (sugar in Barbados, bananas in the Windward islands, etc.). Note, however, that this occurred because preferences were granted for a limited number of products only, or were particularly large for these products and not for others (the EU sugar and banana protocols under the ACP agreements). With a broader set of preferences, this issue is not as much of a problem. For example, recent assessments of the Everything But Arms agreement which covers basically all commodities find little of this artificial specialization, even though it is likely that some foreign investment in the sugar industry in some LDCs would not have taken place if the EU market was open to Brazilian exports (Gallezot and Bureau, 2005; Yu and Jensen 2005).

A criticism of preferences is that they simply divert trade. Preferences are, by nature, a source of trade diversion, and it is understood and accepted that, say, the GSP diverts trade towards developing countries. However, trade diversion occurs also between developing 
countries. Countries such as Brazil and India complain about the benefits granted to sub Saharan Africa under the Cotonou agreement. Caribbean countries expressed strong criticisms when the EU adopted the Everything But Arms initiative, fearing competition for their banana and sugar exports. Sri Lanka complains about losing some market shares to Bangladesh because of the EU and US GSP for LDCs.

The particular trade diversion between developing countries generated by the present configuration of preferences lacks justification. Some non reciprocal preferences are characterized by arbitrariness. The EU preferences seem very tied to historical and colonial links, and the US are dependent on geo-political aspects. However, there is a stronger justification for providing a specific treatment for countries that cannot pull themselves out of a poverty trap, or which have consistently failed to take advantage of trade liberalization (Cline 2004). LDCs fall into these categories, and, as Cline shows, the entire sub-Saharan Africa is also in a situation that calls for particular measures, compared to most Asian countries. Preferences based on a formula taking account of the degree of a country's development are more defensible. When provided to the poorest countries, preferences are unlikely to result in large negative effects for other developing countries: the Everything but Arms has not generated significant trade diversion from developing countries. A concomitant increase of trade with other developing countries (intra LDCs in particular) has even been observed. Although it is difficult to establish a causal link, it has been suggested that preferential access to the EU has helped to build export capacities and had a spillover effect (Gallezot and Bureau 2005).

The most relevant objection to granting preferential access to developing countries in agriculture is perhaps that it is difficult to agree on eligibility criteria. The per capita income is an obvious choice to decide which country should be eligible for preferences. However, countries that are only slightly less poor than, say, the LDCs which are granted preferences, would suffer from a threshold effect. Another point is that agricultural preferences are likely to lose significant value in the future, because of the decrease in multilateral tariffs, and the reform of domestic policies, for example in the EU and US sugar sectors.

Are preferences ineffective in the agricultural sector and would their erosion be harmless? Table 5 show that preferential regimes for developing countries account for a significant share of the imports of agricultural and food products $(20 \%)$ into the EU. They account for $12 \%$ of all US imports in this sector, but it is noteworthy that a large share of imports is subject to a zero MFN duty. However, the preferences granted to very poor countries fail to generate large trade flows: in spite of the absence of quotas and tariffs, the

\footnotetext{
${ }^{4}$ The conditions imposed by the US for eligibility to preferences include many clauses that ensure that only countries protecting US interests will benefit. US preferences include provisions regarding protection of US intellectual property, US investments, and some foreign policy considerations, for example.

It is true that the EBA has had only a marginal impact, and in the only sector where it did so, the sugar sector, trade diversion could take place if Caribbean countries were no longer granted exclusive import quotas.
} 
EU Everything But Arms initiative only represents $0.4 \%$ of EU agricultural and food imports (even though many eligible imports enter duty free under competing agreements). The US African Growth Opportunity Act represents only $0.2 \%$ of US food imports, and most of them come from the South African Republic. From this perspective, the impact of the preferences granted to poorest countries is disappointing. The explanation for this is to be sought in problems of competitiveness or in poor compliance with sanitary standards or plant disease controls more so than in the side conditions of preferential agreements (OECD, 2005). For example, the Everything But Arms initiative led to considerable preferential margins in the animals and meat sectors, given the very high EU tariffs and the absence of coverage by the regular GSP for these products. However, there has been no significant export to the EU, even though animals is a sector where LDCs have some significant export potential (live sheep and beef exported to the Middle East and to other developing countries). Sanitary obstacles have prevented the large tariff cuts translating into exports to the European Union.

It is difficult to evaluate the impact of preferences on growth and development. The European Commission itself expressed serious doubts about the benefits of the ACP preferential regime during the design of the Cotonou agreement. However, statistical studies showing the ineffectiveness of preferences (Ozden and Reinhardt, 2003; Stockel and Borrell, 2001) are not particularly convincing. Perhaps the situation would have been much worse without preferences. Table 5 shows that the Cotonou agreement and the GSP cover significant exports to the EU, and it is unclear whether such flows would take place without these preferential regimes. Moreover, several recent studies contradict assertions of the ineffectiveness of preferences as development aid, at least in the agricultural sector. In a very detailed study of African countries, Stevens and Kennan (2004) show that preferences in textile but also in agriculture and fisheries "are used and work" on a global scale, and that the problems are caused more by the limitations of these preferences (limited product coverage, restrictive conditions, problems of technical standards imposed for tariff exemptions, etc.). Clearly, some trade flows would not have taken place without these preferences. This is confirmed by Wainio and Gehlhar (2004) who also show that exports from developing countries fell when preferences have been eroded by the lowering of US tariffs imposed on competing countries. A statistical study conducted over a wide sample of countries even suggests that countries which benefit from the American and/or European GSP on average have experienced significant extra growth (Romalis, 2003).

There remain important questions for which precise information is lacking. This is true regarding the extent of the real benefits to developing countries, and more so for the sharing of these benefits. What exactly are the repercussions of the ACP agreements for various categories of the population? How are the preferential rents (including import quota rents) distributed? What are the indirect effects (corruption) of import or export license allocation? It is not known precisely if this "Trade as Aid" is more effective than more direct assistance policies, the consequences, for example of the EU banana and sugar protocols being controversial on this point. However, excessive criticism of preferential regimes seems to be made in order to avoid the defense of preferences being used as an obstacle to multilateral liberalization (Anderson 2004). By doing so, one takes the risk of depriving many developing countries of assistance which may be quite effective. 
Table 5. EU and US imports of agro-food products under various regimes, year 2002

\begin{tabular}{|c|c|c|c|}
\hline Regime & Country eligible & $\begin{array}{l}\text { Value of } \\
\text { imports }\end{array}$ & $\begin{array}{l}\text { Share in } \\
\text { total imports }\end{array}$ \\
\hline EUROPEAN UNION & & $\begin{array}{l}\text { Millions } \\
€ \text { ou } \$\end{array}$ & \\
\hline Preferential imports from developing countries & & 13316 & $20.01 \%$ \\
\hline Non reciprocal preferences & & 0 & \\
\hline Cotonou & Africa, Caribbean, Pacific & 5500 & $8.26 \%$ \\
\hline GSP (excluding East Europe) & Almost all developing countries & 4257 & $6.40 \%$ \\
\hline SGP "plus" (drugs) & Countries fighting drug trafficking & 1714 & $2.58 \%$ \\
\hline Everything but arms & Least developed (except Myanmar) & 294 & $0.44 \%$ \\
\hline Others & Overseas territories. & 399 & $0.60 \%$ \\
\hline \multicolumn{4}{|l|}{ Reciprocal preferencess } \\
\hline $\begin{array}{l}\text { Bilateral agreements with developing } \\
\text { countries }\end{array}$ & Maghreb, Mashrek, etc. & 1153 & $1.73 \%$ \\
\hline $\begin{array}{l}\text { Imports under a zero MFN duty from developing } \\
\text { countries }\end{array}$ & All developing countries & 15567 & $23.39 \%$ \\
\hline Imports under a non zero MFN duty from develop & ping countries & 11724 & $17.61 \%$ \\
\hline Total imports from developing countries & & 40737 & $61.20 \%$ \\
\hline Total EU imports & & 66559 & $100.00 \%$ \\
\hline \multicolumn{4}{|l|}{ UNITED STATES } \\
\hline Preferential imports from developing and emergin & ng countries & 7607 & $12.70 \%$ \\
\hline \multicolumn{4}{|l|}{ Non reciprocal preferences } \\
\hline Africa Growth Opportunity Act & Sub Saharan Africa & 137 & $0.23 \%$ \\
\hline Andean Trade Promotion Act & 4 andean countries & 408 & $0.68 \%$ \\
\hline Caribbean Basin Initiative & Caribbean and Central America & 1629 & $2.72 \%$ \\
\hline GSP (except Eastern Europe) & Most developing countries & 1350 & $2.25 \%$ \\
\hline GSP for LDCs & US list of LDCs & 17 & $0.03 \%$ \\
\hline \multicolumn{4}{|l|}{ Reciprocal preferences } \\
\hline $\begin{array}{l}\text { Bilateral agreements with developing } \\
\text { countries }\end{array}$ & Jordan, Gaza, Chili, etc. & 22 & $0.04 \%$ \\
\hline Mexico under the NAFTA & Mexico & 4044 & $6.75 \%$ \\
\hline \multicolumn{2}{|c|}{ Imports under a zero MFN duty from developing countrie } & 20811 & $34.74 \%$ \\
\hline \multicolumn{2}{|c|}{ Imports under a non zero MFN duty from developing countries } & 14 & $0.02 \%$ \\
\hline \multicolumn{2}{|l|}{ Total imports from developing countries } & 28417 & $47.43 \%$ \\
\hline \multicolumn{2}{|l|}{ Total US imports } & 59910 & $100.00 \%$ \\
\hline
\end{tabular}

Source: Authors using data from Gallezot, souceTaxud and TARIC-Eurostat and from USITC. Figures for 2002, Chapters 1 to 24 of the Harmonized system. GSP indicates the Generalized system of preferences. MFN stands for Most favorite nation. 
In addition, skepticism about the benefit drawn from preferences does not imply that their removal would be harmless. Various authors have argued that erosion of non-reciprocal preferences is a problem of limited magnitude at the worldwide level, focused on a handful of products and on a limited number of countries (see e.g. Subramanian, 2003; Alexandraki and Lankes, 2004). However, Bouët et al (2005) argue that the magnitude of forthcoming difficulties for poor countries has been understated. According to their estimates, 14 countries earned in 2001 tariff quota rents worth more than half a percentage point of their GDP (more than one point in 8 countries). ${ }^{6} \quad$ Their calculation also shows that the "true" average preferential margin in agriculture is higher than 1 point for 47 developing countries, and higher than 2 points for 33 countries. Bouët et al stress that preferential schemes such as the EU-Cotonou Agreement or the US-Caribbean Basin Initiative are of particular importance for beneficiary countries. The erosion of preferences is likely to be a major challenge for several African and Caribbean countries, whose export specialization is in large part shaped by preferences. Sugar, bananas, textiles and clothing, and meat products figure largely in the preferences debate, but these products are key for numerous developing countries.

Furthermore, the poor countries concerned generally have a very low adjustment capacity due to the combination of an often-deficient capital market, of the existence of many obstacles to labor mobility, of the absence of safety nets and of training capacities, etc. They might well face severe difficulties when trying to reallocate part of their production factors toward other sectors. Contraction of internal demand is often the only domestic way for them to adjust to external imbalances.

\section{THE IMPACT OF DOMESTIC SUBSIDIES}

Farm support increasingly decoupled. Tariffs are often seen as being the main issue that should be tackled by trade negotiators. Anderson and Martin (2005), for example, believe that $92 \%$ of the gains of agricultural liberalization are expected to be found in the reduction of tariffs, while the elimination, or reform of agricultural subsidies would have only limited impact. However, the impact of domestic subsidies may not be as harmless as this figure suggests.

\footnotetext{
${ }^{6}$ There is little original work on the actual allocation of the rents. Borrell (1999) or Topp (2003) who suggest that the banana protocol brings almost no benefit to developing countries, while costing much more to EU consumers, are often quoted. However, as noted by FAO (2004), the authors provide little empirical justification and theoretical basis for their claims. Some evidence suggests that, under the sugar protocol, countries such as Mozambique or the Windward islands have managed to condition the attribution of licenses to the funding of public services or schools, and have therefore kept at least a fraction of the preferential rent. In Guyana, the rent is estimated to amount to $10 \%$ of GDP and is the backbone of Guyanese economy (LMC, 2004). The rent of sugar and orange juice preferences is described as having a significant positive impact on the expansion of some income-generating sectors in Guyana and Belize (FAO, 2004). Stevens (2003) shows that the allocation of quotas under the Cotonou sugar protocol provides some market power to the ACP countries when facing a trading firm, allowing them to keep some of the rent (he shows that a monopsonist in the sugar sector cannot play one supplier off against another as this firm does in other situations with no allocated quota).
} 
The overall welfare effect may hide some large, but contradictory effects, that offset one another, generating losses in some food importing countries and gains in others. The removal of EU and US agricultural subsidies may, for example have significant consequences on the world price of some commodities. This is the case of the subsidies on cotton, tobacco and even soybeans. Bouët et al (2004a) find for example that elimination of US payments to cotton producers would lead to large increase in the world price (US exports amounting to some $40 \%$ of world trade). Albeit contrasted across countries, the impact of EU and US domestic subsidies on developing countries should not be underestimated. With a significant cut in US and EU cotton subsidies, the share of Sub Saharan Africa in the world trade could increase dramatically. On the other hand, textile producing countries that cannot produce cotton within their own borders could lose market shares in clothing to countries such as China, and suffer from a degradation in their terms of trade.

It is even more difficult to assess the impact of domestic subsidies in sectors where payments are less linked to production. Recent agricultural policy reforms have been characterized by a move of farm support towards payments which are less tied to the quantity produced. Payments coupled to production count for only marginal amounts in the European Union or in the United States in the cereal or meat sectors, for example. As a result, "green box" payments (which, in WTO terms, refers to transfers to farmers which are not dependent on either current prices or the quantity produced) are now very large.

Some developing countries, backed by non governmental organizations such as Oxfam, argue that decoupling is only a cosmetic revamping of support which remains at the same level (Watkins, 2004). However, one cannot deny that decoupled payments are much less distorting than the former market price support and output subsidies. The main question is perhaps whether EU and US payments are actually decoupled. OECD estimates suggest that the combination of payments linked to production and market price support (i.e. the "coupled") form of payments still exceeds the amount of transfers to producers that are genuinely decoupled. In the EU, the decoupling is only partial, and the new "single farm payment" remains conditional on the maintenance of the land in good agricultural condition, even though it does not require actual production. In the US, "countercyclical" payments top up some lump sump payments, depending on market conditions. As a result, the combination of payments is de facto linked to the market price. The considerable subsidies given to the crop insurance program are also linked to market situation. In such cases the overall linkage of the payment to the quantities produced is unclear. More generally, payments are only truly "decoupled" if the capital market is perfect, and if private consumption decisions are separable from the production side of the household. Several studies make it clear that to give a sum of money, even unconditionally, to a farmer necessarily influences the amount produced (Chavas and Holt 1990; Sumner 2003). In reducing the risk of insolvency, even decoupled payments encourage higher production or

${ }^{7}$ The 2005 estimates of the Producer support estimates show that the market price support and the payments linked to output, i.e. the two types of support that are clearly not decoupled for production amount to some 182 billion dollars out of a total of 280 billion dollars in the OECD, see OECD (2005b). 
riskier cultivation. There is often an implicit anticipation that cultivated areas will be used as a reference in the next reform which keeps land in cultivation.

Developing countries complain about the indirect distortions generated by "decoupled payments". There are few solid quantitative results on the effect of such aid on production (Adams et al 2001). A recent study by Abler and Blandford (2005) suggest that the effects on the quantities produced are limited. However, many model builders use the rule of thumb (for lack of more exact assessments) that decoupled payments have about one third of the production impact of coupled payments. If this were true, the impact of some 35 billion euros of EU direct aid, and some 30 billion dollars of US payments (OECD 2005b) are far from neutral on the world market and thus on developing countries.

During the Doha negotiations, developing countries have attempted to call the "green box" into question. The criteria for current green box eligibility are debatable and it is likely that the developing countries will resume the offensive on this point. The recent WTO panel finding on American cotton subsidies which recognized the validity of arguments contesting the decoupled status of aid to US cotton could encourage a more offensive stance. The same argument could also be applied to the aid which the EU classifies in the green box, even after the recent reform of June 2003. The results by most economic models suggest that developing countries can only expect little gains from a strong reduction in these direct payments (Anderson and Martin 2005). This conclusion is subject to uncertainty regarding the proper way to model these payments, which parallels the imperfect knowledge of their economic impact (Gohin 2005).

\section{EXPORT SUBSIDIES}

EU export refunds. EU resistance to renouncing export subsidies has been one of the main blocking points during the Doha agricultural negotiations. At an economic level, export subsidies are a very inefficient support instrument. A large share of the money spent by the taxpayer benefits foreign consumers. However, for the EU, renouncing the possibility of subsidizing exports is the same as renouncing the maintenance of an intervention price structurally higher than world prices: European "refunds" are the keystone of the common market organizations. The August 2004 agreement foresees the ending of export subsidies, although without an exact date (WTO 2004). It is likely that this will require further adjustments in the Common Agricultural Policy, and in particular a further decrease in intervention prices.

Have export subsidies (essentially EU subsidies in the last few years) had a very negative impact on developing countries? Such subsidies face strong criticism from various non governmental organizations who highlight the unfair and harsh competition in some industries: beef and poultry in West Africa, milk in Jamaica or in India. These effects are real, especially as the amounts concerned can vary considerably from one year to the next according to the quantities which must be removed from the European market to support prices. However, they are not uniform. Developing countries which are net importers of food benefit from more favorable terms of trade. They largely abstained from condemning 
too openly these export subsidies during the Doha round, because they reduce the price they pay for imports.

A recent study by Gallezot and Bernard (2004) reviewed the amounts and destinations of European export subsidies. It shows that they vary considerably according to the product but also to the destination, the main subsidies being granted to milk powder and sugar, those on beef and poultry now representing only limited quantities. According to this study, subsidies are principally aimed at countries that are dependent on imports. It is difficult, however, to assess the responsibility of these subsidies for the inability of local farmers to develop local adequate agricultural production and it is undeniable that the subsidies are unfair competition for other potential suppliers.

The end of export refunds. European subsidies have clearly limited trade in the South, depriving some countries with significant production potential of markets in nearby countries. In some sectors, such as West African beef, these subsidies frequently represent half the cargo value. Nevertheless, the removal of subsidies would not greatly alter the situation for developing countries, except for the particular cases underlined by the NGOs. The assessments of Bouët et al (2004a) suggest that such removal will have an important effect on the world price only in the sugar and dairy product sectors. The end of refunds will hardly have any impact on those developing countries which sell their sugar higher than the world price in the framework of preferential quotas. With dairy produce, only some developing countries like Argentina have a definite comparative advantage. Subsidized exports of milk affect essentially West Africa, which historically does not have significant production potential. In short, the removal of such subsidies is desirable to end unfair competition, but the overall positive effect on developing countries must not be overestimated, and the consequences are, at least in the short term, negative for the net food importing countries.

\section{THE EFFECTS OF DOHA}

The assessment of the effect of the Doha Round by Bouët et al (2004a) stands out by the fact that preferential regimes granted to developing countries are considered very carefully, markedly altering the conclusions that can be drawn from such exercises for the developing countries. In particular, this study shows that the lowering of Most Favored Nation (MFN) duties by Northern countries erodes the preferences granted to sub Saharan Africa and modify significantly the origin of EU imports. Countries such as Australia or Brazil would then replace some of the preferential exports of Africa, the Caribbean or the Andean countries.

\footnotetext{
${ }^{8}$ As the August 2004 agreement is imprecise on the technical modalities of tariff and internal support reductions, hypotheses were made on the basis of the Harbinson draft compromise (WTO, 2003). However, the simulations carried out should be close enough to those of the final agreement.
} 
The reduction of internal support would have a more significant effect than other measures in the rice, cotton and, to a lesser degree, the cereal and oil crop sectors (Bouët et al, 2004a). In the sugar sector, the removal of export subsidies would have the most significant impact. In the other sectors, particularly fruit and vegetables, it is the lowering of tariffs which is most important.

Apart from significant impacts on the world price of rice, milk and sugar, the price effects of the Doha round will be small. Growth in production would certainly occur for developed countries in the Cairns group and, to a lesser extent, developing countries of the same group (Brazil, Argentina and Thailand particularly). It is principally the exports of the Cairns group (and to a lesser degree, China and the East-Asian developing countries) which would increase, to the detriment of EU exports. African countries would see no significant growth in their exports, because they can already access the EU market with little tariff protection.

The welfare effects in developing countries presented in Table 6 are the combination of changes in their terms of trade, allocative efficiency, government revenues, as well as gains for agricultural producers and losses for consumers. In Mediterranean countries and subSaharan countries, the welfare effect of the Doha Round would be negative. In subSaharan countries, this is caused by the erosion of preferences, which leads to both a lower rent and some trade diversion. In Mediterranean countries, this is due to both the erosion of preferences and the deterioration of their terms of trade, caused by higher import prices for cotton (an input of the textile industry) and food products. Other developing countries (Asian and some South American countries) would experience a net increase in welfare, but by a limited amount (Table 6 , and Bouët et al 2004a for more details). Some of the poorest countries, or at least some countries that include the largest number of the poor, such as India or Pakistan (part of "South Asia" in Table 6) experience a slight increase in welfare, mainly due to allocative efficiency gains generated by the elimination of their own domestic distortions. However, others, also among the poorest, experience welfare losses. This is the case of sub-Saharan Africa, which includes many of the least developed countries

Note that the farm sector in sub-Saharan Africa benefits from higher world prices, even though trade liberalization hurts consumers. This is not the case in South Asia, because of larger cuts in agricultural tariffs (an indication of the effects on the farm sector is given by the returns to agricultural land in Table 6). This shows that the domestic risks would be different across countries: more expensive food for the urban population could lead to some instability in one case, while the risks could come from a stressed farm sector in the other case. Recent studies focusing on the poverty impact of trade liberalization, which combine household surveys with economic models, also show the uneven consequences on different population groups (see e.g. Hertel and Winters 2005). Welfare gains at the national level can even be compatible with a larger number of people below the poverty level (Bussolo et al 2004; Valenzuela et al 2005). This calls for flexibility in implementing the measures in final Doha agreement, so that individual developing countries can adapt to the local situation. Such flexibility is included in the special and differential treatment of Framework agreement, at least in a limited extent (WTO 2004). 
Table 6. Impact of an agreement on agriculture in the Doha round (percentage changes compared to a 2005 reference)

\begin{tabular}{lccccc}
\hline & $\begin{array}{c}\text { Changes in food } \\
\text { and agricultural } \\
\text { production }\end{array}$ & $\begin{array}{c}\text { Agri-food } \\
\text { Exports }\end{array}$ & $\begin{array}{c}\text { Agri-food } \\
\text { Imports }\end{array}$ & $\begin{array}{c}\text { Returns to } \\
\text { agricultural land }\end{array}$ & $\begin{array}{c}\text { Changes in } \\
\text { global welfare }\end{array}$ \\
\hline EU 25 & -1.57 & 2.7 & 12.8 & -15.06 & 0.14 \\
USA & -1.05 & 0.8 & 2.8 & -0.21 & 0.05 \\
Asia Developed & -2.08 & 11.8 & 9.6 & -1.79 & 0.05 \\
EFTA & -2.73 & -3.8 & 3.7 & 1.10 & -0.11 \\
Cairns Developed & 3.66 & 12.8 & 2.8 & 1.08 & 0.04 \\
Mediterranean & 0.73 & 8.8 & -1.5 & 0.77 & -0.16 \\
Cairns Developing & 1.25 & 10.4 & -0.7 & 0.60 & 0.00 \\
China & 0.01 & $13 . .2$ & 10.1 & 0.30 & 0.15 \\
RoW & 0.64 & 6.8 & -0.7 & 1.15 & -0.10 \\
South Asia & -0.01 & 6.4 & 7.8 & -0.10 & 0.17 \\
SubSaharan Africa & 0.76 & 4.7 & -0.8 & 0.22 & -0.03 \\
World & $\mathbf{- 0 . 3 9}$ & $\mathbf{6 . 1}$ & $\mathbf{6 . 0}$ & - & $\mathbf{0 . 0 8}$ \\
\hline
\end{tabular}

Source: Bouët et al 2004a.

\section{NON TARIFF ISSUES AND DEVELOPING COUNTRIES}

The share of developing countries in world agri-food exports has continually decreased, from $40 \%$ to $24 \%$ in thirty years. Sub-Saharan Africa's market share has declined from $9 \%$ to less than $3 \%$, and consists essentially of raw or lightly processed products. One reason is that developing countries have largely remained outside the phenomenon of intra-regional liberalization, which has increased trade within large areas of the world. Neither African nor Asian regional integration has been very convincing and Mercosur's integration remains incomplete. Overall, developing countries continue to impose very high tariffs among themselves, often adding non transparent import taxes and a multiplicity of bureaucratic obstacles. Some estimates find that the gains for developing countries obtained by eliminating tariffs between themselves exceed the gains obtained by cutting developed countries tariffs (Anderson and Martin, 2005). ${ }^{9}$

Sanitary and technical issues. Another reason for the lack of integration into the world market is because technical, sanitary and plant disease controls restrict agricultural and food exports from a large number of developing countries. These problems are particularly acute with primary products, due to measures against epidemics, contagious diseases or

Note, however, that the preferences granted under many South South agreements are still not very well taken into account in the existing data. Bilateral tariff concessions are not fully transparent in the agreements, and it is unclear how they are captured by United Nations statisitcs. Recent work suggest that there are particular tariff exemptions for some members, and a degree of special and differential treatment within agreements such as the Common Maket for Eastern and Southern Africa, the South African Custom Union, the Economic Community of Central African States, the South African Free Trade Agreement, the Pacific Island Countries Trade Agreement, the Andean Community, the Latin American Integration Association and the Caribbean Community, etc. (Lejarraga, 2005). It is possible that available data still leads to overestimates the gains of South-South liberalization. 
invasive species. For example, the EU prohibited the import of African fish and shellfish at the end of the 1990s for fear of cholera, severely handicapping one of this region's few dynamic sectors. Numerous countries that are not deemed to be free of foot and mouth disease cannot export animal products: for these, the opening of markets by an agreement within the Doha Round would be largely theoretical. The phytosanitary barriers to the importation of fruit and vegetables are very restrictive and sometimes unpredictable, and lead to penalizing retention periods (this is also the case in Japan and Australia, see OECD, 1999).

It might be thought that sanitary and pest control problems, especially questions of microbe contamination and invasive species, would be less of a problem for processed products. These, however, do not gain easier entry to the European or American market. Indeed, standards imposed by the developed countries often concern the processing chain and not only the final quality of the product (Henson et al 2000). Food firms must observe the technical standards and Hazard Analysis at Critical Control Points procedures which pose problems of cost, infrastructure and traceability for developing countries.

The SPS Agreement (on sanitary and phytosanitary standards) states that more restrictive controls than those based on international standards must have scientific justification based on risk analysis. Nevertheless, the SPS Agreement has a limited value for developing countries, which have made only infrequent use of it to open markets. The agreement favors countries which have accumulated significant expertise in the field of scientific evaluation used in arbitration cases, and because it only includes very minor references to economic issues, it allows developed countries to act against very small risks. The special and differential treatment for developing countries (Article 10 of the SPS agreement and Article 12 of the Technical Barriers to Trade or TBT agreement, which recommend giving consideration to the difficulties for developing countries to comply with Northern standards) has had little effect. It is easily understood that, with public opinion so sensitive on matters of food safety, caution encourages very restrictive measures. However, the fact is that technical conditions placed on the exports of developing countries are de facto obstacles which limit the effects of lowering customs tariffs.

The increasing significance of private standards. Perhaps a more significant phenomenon is that the standards governing international (and national) trade are increasingly beyond public control, which alone is capable of being the subject of international agreements. Increasingly, private players are imposing their own standards on importers and producers from developing countries (Reardon, 2004). These requirements exceed public regulations, particularly regarding production processes, certification and traceability, three areas where the poorest countries are especially handicapped by the lack of capital, infrastructure and skilled workers. Moreover, private sector standards appear to amplify the effects of reputation, distributors in developed countries having not only to manage the risk but the media coverage of risk with public opinion. It was found that, out of fear of potential risks, there are importers (e.g. those involved in school meals) who systematically refused supplies from developing countries despite a seemingly satisfactory bill of health (Bureau et al, 2004). 
In short, there is a set of factors not pertaining to negotiation on tariffs which considerably limit the integration of developing countries into the world market. More generally, there are supply side constraints, such as infrastructure, capital and skilled labor constraint, that will limit considerably the impact of tariff concessions in the food sector. Again, not all developing countries are affected in the same way. For example, Blasetti and Piniero (2003) show that the food sector in Argentina and Brazil is confident of its capacity to respond to all EU technical and sanitary requirements in the near future, even if those on traceability pose some problems for Argentina exporters (it is also problematic for other developed countries). Non-tariff factors seem to marginalize the poorest countries the most, and sub Saharan Africa in particular.

\section{CONCLUSION}

This paper highlighted the contrasting interests of various types of developing countries faced with the perspective of liberalization in the agricultural and food sector. For most middle-income developing countries confronted with high protection in their main markets, liberalization can be a source of substantial growth in prospects and prices for a relatively high-performing export sector. For net food importing countries, including most of the LDCs and the small island developing states, and for cotton importing countries (North Africa, Bangladesh), agricultural trade liberalization may have overall negative consequences, because of terms of trade effects. For most sub-Saharan Africa and LDCs, negative consequences also result from the erosion of their preferential access to the EU and US market. For poorest countries, non tariff issues and supply side constraints are likely to limit even further the possible expansion of their exports that could result from more open agricultural markets.

These constrasting effects have long been underestimated. They are now supported by a growing body of quantitative analyses that have challenged the idea that cutting agricultural tariffs and ending farm subsidies would benefit developing countries as a whole. However, showing that the situation is complex has not made the policy message simpler. Indeed, while it becomes clear that some of the poorest countries are likely to lose from an agricultural agreement in Doha, some of the beneficiaries include a large number of poor people (China, India, Brazil, Thailand). In addition, in net food importing countries, the large losses for some agents consumers are offset, at least partially, by gains for other agents (urban consumers $v s$ farmers).

The fact that some countries lose from the erosion of preferences is hardly a justification for rejecting the multilateral process of trade liberalization. However, equity, as well as the need to gather a consensus for the continuation of a multilateral process, requires acknowledging the negative impacts, and looking for ways to compensate or reduce them.

Under the WTO, the Special and Differential (S\&D) treatment mainly consists in a lower level of obligations and longer implementation periods to phase in trade discipline. Basically, these are mainly options for opting out the liberalization process, which are unlikely to alleviate possible negative effects resulting from multilateral liberalization in third countries (Matthews, 2005). If the international community wants to offset some of 
the negative effects of the Doha round, more ambitious and positive measures must be implemented than the provisions of the Uruguay Round Agreement on agriculture, or the declarations of intention of the SPS and TBT agreement, or the 1994 Declaration on Net Food Importing Developed Countries.

Several forms of direct assistance for those countries adversely affected by trade liberalization have been proposed (Prowse 2005; Page 2005). They include the constitution of special funds or the use of financial facilities. The 1960s conception of special and differential treatment, which relied a lot on trade preferences for developing countries, such as the GSP, is often seen as carrying too many unwanted consequences. The recent growth of criticism of trade preferences doubtless responds to anxieties as to their often arbitrary and even, in some cases, harmful character. Countries excluded from the benefits of such agreements can legitimately feel wronged. The fear of seeing the defense of preferences used in the defense of protectionist interests is another reason for distrust. Finally, the argument that preferences can only be a short term policy, given the progressive reduction of multilateral tariffs and the reform of agricultural policies in developed countries, cannot be ignored. However, these critiques of preferential regimes underestimate the growing difficulty of the poorest countries in the export of agricultural produce. Their marginalization can only increase if no measures are taken in their favor. In this case, equality of treatment is not synonymous with fairness.

Among the 148 WTO members, more than 100 are treated as developing countries, including Singapore and Korea as well as Haiti and Liberia. The extent of their economic weakness, which special and differential treatment is supposed to address, varies greatly. If special and differential treatment is seen as a form of adjustment to the outcome of the Doha negotiations, one must acknowledge that Brazil or China and Bangladesh or Mauritius will benefit very unevenly from the negotiations.

Better differentiating between developing countries is necessary to move forward. In this perspective, simple reference to historical or geographical criteria is arbitrary and ill-suited. Only a more objective approach, contingent exclusively on widely accepted development criteria would provide the basis for a redefinition of fairness in the international trading system. In order to reach a fair agreement, the option of demanding that the countries that benefit most from the Doha round (including some developing countries), should apply low or zero tariffs on imports from the poorest, or the more vulnerable countries, should be explored. If a set of intermediate countries also decided to grant GSP preferences to the poorest, for the latter, the expansion of their market could offset some of the losses caused by multilateral liberalization. This would also help them benefit from increased access to the most rapidly growing markets, where quality standards are perhaps more accessible.

A more differentiated list of countries carries the risk of adding complexity to an already overwhelmed multilateral regime. An option could be a coordinated reconsideration of all existing preferences, and the move towards a reformed GSP, which would discriminate more against countries so as to target those that benefit less from liberalization. This would be perhaps the beginning of a multi speed system, more adapted to the diversity of situations. 


\section{REFERENCES}

Abler D. and Blandford D. (2005). A Review of Empirical Studies on the Production Impacts of PFC and MLA Payments Under the US FAIR Act. Consultants report, Organization for Economic Cooperation and Development, Paris.

Adams G., Westhoff P., Willott B., and Young R.E. II (2001). Do 'Decoupled' Payments Affect US Crop Area? Preliminary Evidence from 1997-2000, American Journal of Agricultural Economics 83 (2001), pp. 1190-1195.

Alexandraki K. and Lankes H. P. (2004). The Impact of Preference Erosion on MiddleIncome Developing Countries, IMF Working Paper 04/169, IMF, Washington DC, September.

Anderson K. (2004). Subsidies and Trade Barriers. In Global Crisis, Global Solutions, B. Lomborg editor, Copenhagen Consensus Challenge. Cambridge University Press

Anderson K. and Martin W. (2005). Agricultural Trade Reform and the Doha Development Agenda. Working paper WPS3607, The World Bank, May version.

Blasetti R. and Pineiro M. (2003). La negociacion Union Europa-Mercosur: Medidas sanitarias y fitosanitarias y otros obstaculos potenciales al comercio de productos alimentarios. Working Group on EU-Mercosur Negotiations meeting, Mercosur Chair of Sciences Po and Inter American Development Bank, Jan 31.

Bouët A., Bureau J.C., Decreux Y. and Jean S. (2004a). Multilateral Agricultural Trade Liberalization: The Contrasting Fortunes of Developing Countries in the Doha Round, Working paper, Centre d'études prospectives et d'économie internationales, December (forthcoming in World Economy).

Bouët A., Decreux Y., Fontagné L., Jean S. and Laborde D. (2004b). Computing an Exhaustive and Consistent, ad-valorem Equivalent Measure of Applied Protection: A Detailed Description of MacMap-HS6 Methodology, Working paper, Centre d'Etudes Prospectives et d'Informations Internationales, CEPII, Paris.

Bouët A., Fontagné L. and Jean S. (2005). Is the Erosion of Preferences a Serious Concern?. In Agricultural Trade Reform and the Doha Development Agenda, K. Anderson and W. Martin, eds, Oxford University Press and The World Bank.

Brenton P. (2003). Integrating the Least Developed Countries into the World Trade System: The Current Impact of EU Preferences under Everything But Arms, Working Paper, The World Bank. 
Bureau J.C. and Salvatici L. (2004). WTO Negotiations on Market Access: What We Know, What We Don't and What We Should. In Agricultural Policy Reform and the WTO, G. Anania, M. E. Bohman, C. A. Carter and A. F. McCalla, eds, Edward Elgar, Cheltenham, UK \& Northampton MA, USA, pp. 207-251.

Bureau J.C., Bernard F., Gallezot J. and Gozlan E. (2004). The Measurement of Protection on the Value Added of Processed Food Products in the EU, the US, Japan and South Africa., The World Bank, July.

Bussolo M., van der Mensbrugghe D. and Lay J. (2004). A Preliminary Assessment of the Economic and Poverty Impacts of the Doha and FTAA Agenda for Latin America, Working Paper, The World Bank and Kiel Institute of World Economics.

Chavas J.P. and Holt M.T. (1990), An Analysis of Acreage Decisions Under Risk: The Case of Corn and Soybeans, American Journal of Agricultural Economics, 72, pp. 529-538.

Cline W.E. (2004). Trade Policy and Global Poverty. Center for Global Development and Institute for International Economics, Washington DC.

Diao X., Diaz-Bonilla E. and Robinson S. (2004). Tell me Where it Hurts, and I'll Tell You who to Call, International Food Policy Research Institute, Washington.

FAO (2004). Small Islands Developing States. Agricultural Production and Trade, Preferences and Policy, Commodities and Trade Technical Paper 7, Food and Agriculture Organisation, Rome.

Fontagné L. and Mimouni M. (2001). L'environnement, nouvel obstacle au commerce de produits agricoles et alimentaires, Economie Internationale 87, pp. 63-87.

Francois J., van Meijl J. and van Tongeren F. (2003). Economic Implication of Trade Liberalization under the Doha Round, CEPII Working Paper 2003-20, Centre d'Etudes Prospectives et d'Informations Internationales, Paris.

Gallezot J. and Bureau J.C. (2005). The Trade Effect of the Everything But Arms Initiative, Consultants report, European Commission, Directorate General Trade, Brussels.

Gallezot J and Bernard F. (2004). EU Export Subsidies on Agricultural and Agri-food products to Africa, The World Bank, June.

Gallezot J. (2003). Real Access to the EU's Agricultural Market. Report to the European Commission. Directorate General Trade, Brussels. 
Gohin A. (2005). Assessing the impacts of the 2003 CAP Mid Term Review: How sensitive are they to the assumed production responsiveness to Agenda 2000 direct payments?, Paper presented at the $8^{\text {th }}$ Conference on Global Economic Analysis, Lübeck, Germany, June 9-11.

Henson S.J., Brouder A. and Mitulah M. (2000). "Food Safety Requirements and Food Exports from Developing Countries: The Case of Fish Exports from Kenya to the European Union", American Journal of Agricultural Economics, 82 (5), pp. 11591169 .

Hertel T., Hoekman B. and Martin W. (2003). "Agricultural Negotiations in the Context of a Broader Round: A Developing Country Perspective", Chapter 6, In Agricultural Trade Policies in the New Millenium, P.L. Kennedy and W.W. Koo eds, Haworth Press, Inc. New York.

Hertel T. and Winters L. A. (eds, 2005). Poverty Impacts of a WTO Agreemen, Oxford University Press and The World Bank, forthcoming.

Inama S. (2003), Trade Preferences for LDCs: An Early Assessment of Benefits and Possible Improvements, ITCD/TSB/2003, United Nations Conference on Trade and Development, Geneva.

Laird S., Peters R. and Vanzetti D. (2004). Southern Discomfort: Agricultural Policies, Trade and Poverty, CREDIT Research Paper 04/02, University of Nottingham.

Lejarraga I. (2005). SDT in International Trade Arrangements, mimeo, OECD Trade directorate, Organisation for Economic Cooperation and Development, Paris.

LMC (2004). Addressing the impact of preference erosion in sugar on developing countries, Study prepared for DFID, Landel Mills Corportation International and Oxford Policy Management, London.

Matthews A. (2005). Special and Differential Treatment in Agriculture, Organisation for Economic Cooperation and Development, Agricultural Directorate, Paris.

Messerlin P. (2001). Measuring the Cost of Protection in Europe, Institute for International Economics, Washington DC.

OECD (1999). Food Safety and Quality Issues: Trade Considerations / Sécurité et qualité des produits alimentaires: considérations pour le commerce international, Organisation for Economic Cooperation and Development, Paris.

OECD (2005a). Preferential Trading Arrangements in Agricultural and Food Markets: The Case of the European Union and the United State, Organisation for Economic Co-operation and Development, Paris (report by J. Gallezot and J.C Bureau). 
OECD (2005b). Agricultural Policies in OECD Countries. Monitoring and Evaluation 2005, Organisation for Economic Cooperation and Development, Paris.

Ozden C. and Reinhardt E. (2003). The Perversity of Preferences: The Generalized System of Preferences and Developing Country Trade Policies, Working Paper- International Economics, Trade, capital flows series, The World Bank.

Oxfam (2005). A round for free. How Rich Countries are Getting a Free Ride on Agricultural Subsidies. Oxfam, United Kingdom.

Page S. (2005). A Preference Erosion Compensation Fund: A new proposal to protect countries from the negative effects of trade liberalisation. Overseas Development Institute, Opinions, 35.

Panagariya A. (2003). Aid through Trade: An Effective Option?, mimeo, Columbia University, August.

Panagariya A. (2004). Agricultural Liberalization and the Developing Countries: Debunking the Fallacies, mimeo, Columbia University, December.

Prowse S. (2005). "Aid for Trade", Increasing Support for Trade Adjustment and Integration, Department for International Development, United Kingdom, May.

Reardon T. (2004). "Private Standards and the Supermarket Revolution", Standards and Trade Course, The World Bank, Washington DC, 27-28 january.

Romalis J. (2003), "Would Rich Country Trade Preferences Help Poor Countries Grow? Evidence from the Generalized System of Preferences", mimeo, University of Chicago.

Stevens C. (2003). Food Trade and Food Policy in Sub-Saharan Africa: Old Myths and New Challenges, Development Policy Review, 21, 4, 9-38.

Stevens C. and Kennan J. (2004). Comparative Study of G8 Preferential Access Schemes for Africa, Report on a DFID Commissioned Study. Institute of Development Studies, University of Sussex, April.

Stockel A. and Borell B. (2001). Preferential Trade and Developping Countries: Bad aid, Bad Trade, Center for International Economics, Camberra.

Subramanian A. (2003). Financing of Losses from Preference Erosion, International Monetary Fund, Washington DC, January.

Sumner D. A. (2003). Implications of the US Farm Bill of 2002 for Agricultural Trade and Trade Negotiations, University of California Agricultural Issues Center. 
Tokarick S. (2003). Measuring the Impact of Distortions in Agricultural Trade in Partial and General Equilibrium, Working Paper, International Monetary Fund, February.

Topp A. (2003). Are Trade Preferences Useful in Advancing Economic Development?, Working Paper 0503, Australian National University.

Valenzuela E., Hertel T.W., Ivanic M. and Nin Prat A. (2005). Evaluating Poverty Impact of Globalization and Trade Policy Change on Agricultural Producers, Working Paper, Purdue University.

Wainio J., Shapouri S., Trueblood M. and Gibson P. (2003). Agricultural Trade Preferencesand the Developing Countries, Economic Research Report, 6, Economic Research Service, US Department of Agriculture, Washington DC, May.

Wainio J. and Gehlhar M. (2004). MFN Tariff Cuts and U.S. Agricultural Imports Under Nonreciprocal Trade Preference Programs, Presented at the $7^{\text {th }}$ General equilbrium analysis Conference, Washington DC, June.

Watkins K. (2004). "Northern Agricultural Policies and World Poverty: Will the Doha Development Make a Difference"?, Paper presented to the Annual Bank Conference of Development Economics, $15^{\text {th }}-16^{\text {th }}$ May 2003, revised version published by Agence Française de Developpement, Paris.

World Bank. Global Economic Prospects 2004 (2004). Realizing the Development Promise of the Doha Agenda, Washington DC.

WTO (2003). Negotiations on Agriculture. First Draft on Modalities for the Further Commitments TN/AG/W/1/Rev.1/, Committee on Agriculture, Special session, World Trade Organization, 18 March.

WTO (2004). Doha Work Program: Draft General Council Decision of 31 July 2004. WT/GC/W/535 and corrigendum, General Council, World Trade Organization (+ corrigendum).

Yu W. and Jensen T.V. (2005). Tariff Preferences, WTO Negotiations and the LDCs: The Case of the 'Everything But Arms' Initiative, World Economy, 28, 3, 375-405. 


\section{LIST OF WORKING PAPERS RELEASED BY CEPII ${ }^{10}$}

No

Title

2005-12 From Bound Duties to Actual Protection: Industrial Liberalisation in the Doha Round

2005-11 Impact de l'ouverture financière sur les inégalités internes dans les pays émergents

2005-10 Disentangling Horizontal and Vertical Intra-Industry Trade

2005-09 China's Integration in East Asia: Production Sharing, FDI \& High-Tech Trade

2005-08 Tax Competition and Public Input

2005-07 Trade Liberalisation, Growth and Poverty in Senegal: A Dynamic Microsimulation CGE Model Analysis

2005-06 Migration, Trade and Wages

2005-05 Institutional Determinants of Foreign Investment

2005-04 L'économie indienne: changements structurels et perspectives à long terme

2005-03 Programme de travail du CEPII pour 2005

2005-02 Market Access in Global and Regional Trade

2005-01 Real Equilibrium Exchange Rate in China

\section{Authors}

M.H. Bchir,

L. Fontagné \& S. Jean

A. Bénassy-Quéré \&

V. Salins

L. Fontagné,

M. Freudenberg \&

G. Gaulier

G. Gaulier, F. Lemoine

D. Ünal-Kesenci

A. Bénassy-Quéré, N. Gobalraja \&

A. Trannoy

N. Annabi, F. Cissé,

J. Cockburn \&

B. Decaluwé

A. Hijzen \& P. Wright

A. Bénassy-Quéré, M. Coupet \& T. Mayer

S. Chauvin \& F. Lemoine

T. Mayer \& S. Zignago

V. Coudert \&

C. Couharde

10

Working papers are circulated free of charge as far as stocks are available; thank you to send your request to CEPII, Sylvie Hurion, 9, rue Georges-Pitard, 75015 Paris, or by fax : (33) 0153685504 or by e-mail Hurion@cepii.fr. Also available on: \wwww.cepii.fr. Working papers with * are out of print. They can nevertheless be consulted and downloaded from this website.

${ }^{10}$ Les documents de travail sont diffusés gratuitement sur demande dans la mesure des stocks disponibles. Merci d'adresser votre demande au CEPII, Sylvie Hurion, 9, rue Georges-Pitard, 75015 Paris, ou par fax : (33) 0153685504 ou par e-mail Hurion@,cepii.fr. Egalement disponibles sur: |lwww.cepii.fr. Les documents de travail comportant* sont épuisés. Ils sont toutefois consultable sur le web CEPII. 
2004-22 A Consistent, ad-valorem Equivalent Measure of Applied Protection Across the World: The MacMapHS6 Database

2004-21 IMF in Theory: Sovereign Debts, Judicialisation and Multilateralism

2004-20 The Impact of Multilateral Liberalisation on European Regions: a CGE Assessment

2004-19 La compétitivité de l'agriculture et des industries agroalimentaires dans le Mercosur et l'Union européenne dans une perspective de libéralisation commerciale

2004-18 Multilateral Agricultural Trade Liberalization: The Contrasting Fortunes of Developinc Countries in the Doha Round

2004-17 UK in or UK out? A Common Cycle Analysis between the UK and the Euro Zone

2004-16 Regionalism and the Regionalisation of International Trade

2004-15 The Stock-Flow Approach to the Real Exchange Rate of CEE Transition Economies

2004-14 Vieillissement démographique, épargne et retraite : une analyse à l'aide d'un modèle d'équilibre général à agents hétérogènes

2004-13 Burden Sharing and Exchange-Rate Misalignments within the Group of Twenty

2004-12 Regulation and Wage Premia

2004-11 The Efficiency of Fiscal Policies: a Survey of the Literature

2004-10 La réforme du marché du travail en Allemagne : les enseignements d'une maquette

2004-09 Typologie et équivalence des systèmes de retraites

2004-08 South - South Trade: Geography Matters

2004-07 Current Accounts Dynamics in New EU Members: Sustainability and Policy Issues
A. Bouët, Y. Decreux,

L. Fontagné, S. Jean \& D. Laborde

J. Sgard

S. Jean \& D. Laborde

N. Mulder, A. Vialou, B. David, M. Rodriguez \& M. Castilho

A. Bouët, J.C. Bureau, Y. Decreux \& S. Jean

J. Garnier

G. Gaulier, S. Jean \& D. Ünal-Kesenci

B. Egert,

A. Lahrècche-Révil \& K. Lommatzsch

C. Bac \& J. Chateau

A. Bénassy-Quéré, P. Duran-Vigneron, A. Lahrèche-Révil \& V. Mignon

S. Jean \& G. Nicoletti

S. Capet

S. Capet

P. Villa

S. Coulibaly \& L. Fontagné

P. Zanghieri 
2004-06 Incertitude radicale et choix du modèle

2004-05 Does Exchange Rate Regime Explain Differences in Economic Results for Asian Countries?

2004-04 Trade in the Triad: How Easy is the Access to Large Markets?

2004-03 Programme de travail du CEPII pour 2004

2004-02 Technology Differences, Institutions and Economic Growth: a Conditional Conditional Convergence

2004-01 Croissance et régimes d'investissement

2003-22 A New Look at the Feldstein-Horioka Puzzle using a Integrated Panel

2003-21 Trade Linkages and Exchange Rates in Asia :The Role of China

2003-20 Economic Implications of Trade Liberalization Under the Doha Round

2003-19 Methodological Tools for SIA - Report of the CEPII Worshop held on 7-8 November 2002 in Brussels

2003-18 Order Flows, Delta Hedging and Exchange Rate Dynamics

2003-17 Tax Competition and Foreign Direct Investment

2003-16 Commerce et transfert de technologies: les cas comparés de la Turquie, de l'Inde et de la Chine

2003-15 The Empirics of Agglomeration and Trade

2003-14 Notional Defined Contribution: A Comparison of the French and German Point Systems

2003-13 How Different is Eastern Europe? Structure and Determinants of Location Choices by French Firms in Eastern and Western Europe

2003-12 Market Access Liberalisation in the Doha Round: Scenarios and Assessment

2003-11 On the Adequacy of Monetary Arrangements in SubSaharian Africa
P. Villa

V. Coudert \&

M. Dubert

L. Fontagné, T. Mayer \& S. Zignago

H. Boulhol

P. Villa

A. Banerjee

P. Zanghieri

A. Bénassy-Quéré \&

A. Lahrèche-Révil

J. Francois,

H. van Meijl \&

F. van Tongeren

B. Rzepkowski

A. Bénassy-Quéré, L. Fontagné \&

A. Lahrèche-Révil

F. Lemoine \&

D. Ünal-Kesenci

K. Head \& T. Mayer

F. Legros

A.C. Disdier \& T. Mayer

L. Fontagné,

J.L. Guérin \& S. Jean

A. Bénassy-Quéré \& M. Coupet 


\section{CEPII \\ DOCUMENTS DE TRAVAIL / WORKING PAPERS}

Si vous souhaitez recevoir des Documents de travail, merci de remplir le coupon-réponse ci-joint et de le retourner à :

Should you wish to receive copies of the CEPII's Working papers, just fill the reply card and return it to:

Sylvie HURION - Publications

CEPII - 9, rue Georges-Pitard - 75740 Paris - Fax : (33) 1.53.68.55.04

M./Mme / Mr./Mrs

Nom-Prénom / Name-First name

Titre / Title ....

Service / Department.

Organisme / Organisation

Adresse / Address.

Ville \& CP / City \& post code.

Pays / Country. Tél.

Désire recevoir les Document de travail du CEPII $\mathrm{n}^{\circ}$ :

Wish to receive the CEPII's Working Papers No: 